\title{
Impact of Absorbing Layer Band Gap and Light Illumination on the Device Performance of a Single Halide $\mathrm{Cs}_{2} \mathrm{TiX}_{6}$ Based PSC
}

\author{
K. Chakraborty ${ }^{1}$, S. Paul1*, U. Mukherjee ${ }^{2}$, S. Das ${ }^{3}$ \\ ${ }^{1}$ Advanced Materials Research and Energy Application Laboratory, Department of Energy Engineering, \\ North-Eastern Hill University, Shillong793022 Meghalaya, India \\ 2 Department of Life Science, VTT College, Midnapore-721101 West Bengal, India \\ ${ }^{3}$ Department of Electronics and Communication Engineering, IMPS College of Engg. and Tech., \\ Malda 732103, West Bengal, India
}

(Received 10 January 2021; revised manuscript received 15 June 2021; published online 25 June 2021)

\begin{abstract}
A comprehensive study on impact of active layer band gap and light illumination on the device performance has been analyzed for the $\mathrm{FTO} / \mathrm{TiO}_{2} / \mathrm{Cs}_{2} \mathrm{TiX}_{6} / \mathrm{CuSCN} / \mathrm{Ag}$ based Perovskite Solar Cell (PSC) using the Solar Cell Capacitance Simulator - 1 Dimension (SCAPS-1D) simulator. The present design strategy of the device for optimizing the short circuit current $\left(J_{S C}, \mathrm{~mA} / \mathrm{cm}^{2}\right)$, power conversion efficiency (PCE, \%) through the absorbing layer band gap variation, and light illumination spectrum has been studied at the optimal thickness, device temperature, and defect density. The value of the different parameters used in the device simulation has been taken from the previous work. From this study, it was revealed that $\mathrm{Cs}_{2} \mathrm{TiBr}_{6}$, and $\mathrm{Cs}_{2} \mathrm{TiF}_{6}$ absorbing layer based PSC device has recorded maximum PCE at the $1.80 \mathrm{eV}$ band gap, whereas, for the $\mathrm{Cs}_{2} \mathrm{TiI}_{6}, \mathrm{Cs}_{2} \mathrm{TiCl}_{6}$ absorbing layer based PSC device has achieved maximum PCE at the $1.60 \mathrm{eV}$ band gap. On the other side, optimum PCE can be achieved at $400 \mathrm{~nm}$ wavelength on the light illumination for the $\mathrm{Cs}_{2} \mathrm{TiBr}_{6}, \mathrm{Cs}_{2} \mathrm{TiI}_{6}$, and $\mathrm{Cs}_{2} \mathrm{TiF}_{6}$ absorbing layer based PSC. The $\mathrm{Cs}_{2} \mathrm{TiCl}_{6}$ absorbing layer based PSC device has recorded maximum PCE at $450 \mathrm{~nm}$ wavelength on the different light illumination.
\end{abstract}

Keywords: Perovskite solar cell, SCAPS-1D, Photovoltaic, Band gap, Illumination.

DOI: 10.21272/jnep.13(3).03009

PACS numbers: 42.70.Qs, 84.60.Jt

\section{INTRODUCTION}

Solar cell is making for the conversion of solar energy into the electrical energy directly, which has undergone through tremendous development from past few years due to its photovoltaic (PV) properties and that creates a huge interest for researcher community to give their attention towards this area. Initially, $1^{\text {st }}$ generation wafer based PV technology was developed but the production cost was relatively higher with lower conversion ability. The production cost became lower after the introduction of thin film based $2^{\text {nd }}$ generation solar cell but still the power conversion efficiency (PCE) remained low. But both the problem including cost and PCE was nullified after the development of thin film based $3^{\text {rd }}$ generation PV technology. Perovskite solar cells (PSCs) has great capability towards photovoltaic applications and is rapidly emerging as $3^{\text {rd }}$ generation solar cell $[1,2]$. Due to its highly suitable optoelectronic, physical, mechanical and electrical properties like direct band gap, large charge carrier mobility, higher optical absorption coefficient and higher diffusion length makes it ideal for photovoltaic use [3]. The journey started with Kojima et al. (2009) with halide Perovskite $\mathrm{ABM}_{3}$ (A: organic $\mathrm{CH}_{3} \mathrm{NH}_{3}+$; B: $\mathrm{Pb}, \mathrm{X}$ : Br, I) and recorded $3.8 \%$ of power conversion efficiency (PCE, \%) [1]. Later, further extensive research on material, deposition process, fabrication methods and device structure has enhanced the PCE up to $20.1 \%$ experimentally and theoretically $31.4 \%[4,5]$. Despite of such higher conversion efficiency in laboratory, it has several issues towards the commercialization like environment protection from toxic lead $(\mathrm{Pb})$ component, stability under environment conditions due to organic component used in $\mathrm{ABM}_{3}$ structure. To address such issues, researchers are thinking for use of lead-free inorganic material as absorbing material for the photovoltaic applications. Ju et al. (2018) first developed, Cesium Titanium (IV) mixed Halide Perovskite materials which has tunable band gap 1.0-1.8 eV [6]. Chen et al. (2018) achieved $3.28 \%$ PCE, $1.02 \mathrm{~V}$ open circuit voltage $\left(V_{O C}, \mathrm{~V}\right), 5.69 \mathrm{~mA} / \mathrm{cm}^{2}$ current density $\left(J_{S C}, \mathrm{~mA} / \mathrm{cm}^{2}\right)$ and $56.4 \%$ Fill factor $(F F, \%)$ with $\mathrm{Cs}_{2} \mathrm{TiBr}_{6}$ absorbing material in $\mathrm{FTO} / \mathrm{TiO}_{2} / \mathrm{Cs}_{2} \mathrm{TiBr}_{6} / \mathrm{P} 3 \mathrm{HT} / \mathrm{Au}$ structure [7].

In this study, we have studied the photovoltaic parameters $\left(J_{S C}, \mathrm{PCE}\right)$ performance with the absorbing layer band gap, light illumination wavelength for the $\mathrm{Cs}_{2} \mathrm{TiBr}_{6}, \mathrm{Cs}_{2} \mathrm{TiI}_{6}, \mathrm{Cs}_{2} \mathrm{TiCl}_{6}$, and $\mathrm{Cs}_{2} \mathrm{TiF}_{6}$ based absorbing layer PSC.

\section{DEVICE ARCHITECTURE AND SIMULATION}

In our proposed $\mathrm{FTO} / \mathrm{TiO}_{2} / \mathrm{Cs}_{2} \mathrm{TiX}_{6} / \mathrm{CuSCN} / \mathrm{Ag}$ based planar solar cell device model, band gap of ETL materials $\mathrm{TiO}_{2}$ and HTL material CuSCN are taken to be $3.26 \mathrm{eV}$ and $3.4 \mathrm{eV}$, respectively, the absorbing layer is tunable under 1.6-2.4 eV [8-11]. The working temperature for the simulation was maintained at $27^{\circ} \mathrm{C}$ with $-0.8 \mathrm{~V}$ to $0.8 \mathrm{~V}$ bias voltage in the SCAPS-1D simulator. Here, Fig. 1 shows the schematic view of the proposed structure. All the simulation work was carried out with light illumination of $1.5 \mathrm{AM}$ with the $1000 \mathrm{~W} / \mathrm{m}^{2}$ light power under Gaussian energy distribution where characteristic energy was set in $0.1 \mathrm{eV}$. The details of the various properties of the device and the base material taken for the work are shown in Table 1 and Table 2,

\footnotetext{
*paulsamrat17@gmail.com
}

The results were presented at the International Conference on Innovative Research in Renewable Energy Technologies (IRRET-2021) 
respectively. The symbols i.e., $E_{g}$ denotes the band gap energy, $E_{a}$ is the electron affinity, $\varepsilon_{r}$ is the relative permittivity, $N_{A}$ is the acceptor density, $N_{D}$ is the donor density, $N_{t}$ is the defect density, $N_{C}$ is the conduction band effective density of states, $N_{V}$ is the valence band effective density of states, respectively. Default values of some parameters and settings are as: for electron mobility is $4.4 \mathrm{~cm}^{2} / \mathrm{V}_{\mathrm{s}}$, the hole mobility is $2.5 \mathrm{~cm}^{2} / V_{s}$, the electron and hole thermal velocity is $10^{7} \mathrm{~cm} / \mathrm{s}$ [12-14]

\begin{tabular}{c|}
\hline left contact (back) \\
\hline Ag Paste \\
\hline CuSCN \\
\hline Active Layer \\
\hline TiO2 \\
\hline FTO \\
\hline add layer \\
\hline right contact (front) \\
\hline A Hill
\end{tabular}

Fig. 1 - Schematic view of the proposed device structure

Table 1 - Base material properties [9, 11, 12]

\begin{tabular}{|l|l|l|l|}
\hline Properties & $\mathrm{CuSCN}$ & $\mathrm{TiO}_{2}$ & FTO \\
\hline Thickness $(\mu \mathrm{m})$ & 0.35 & 0.14 & 0.1 \\
\hline$E_{g}(\mathrm{eV})$ & 3.40 & 3.26 & 3.60 \\
\hline$E_{a}(\mathrm{eV})$ & 1.90 & 3.70 & 4.0 \\
\hline$\varepsilon_{r}$ & 9.0 & 55.0 & 9.0 \\
\hline$N_{D}\left(1 / \mathrm{cm}^{3}\right)$ & 0 & $4 \times 10^{14}$ & $2.4 \times 10^{18}$ \\
\hline$N_{A}\left(1 / \mathrm{cm}^{3}\right)$ & $1 \times 10^{18}$ & 0 & $1 \times 10^{5}$ \\
\hline$\mu_{n}\left(\mathrm{~cm}^{2} / \mathrm{V}_{\mathrm{S}}\right)$ & $2 \times 10^{-4}$ & 100 & 100 \\
\hline$\mu_{p}\left(\mathrm{~cm}^{2} / \mathrm{V}_{\mathrm{S}}\right)$ & $1 \times 10^{-2}$ & 25 & 25 \\
\hline
\end{tabular}

Table 2 - Absorbing material properties [6, 7, 13-16]

\begin{tabular}{|l|l|l|l|l|}
\hline Properties & $\mathrm{Cs}_{2} \mathrm{TiBr}_{6}$ & $\mathrm{Cs}_{2} \mathrm{TiI}_{6}$ & $\mathrm{Cs}_{2} \mathrm{TiF}_{6}$ & $\mathrm{Cs}_{2} \mathrm{TiC}_{6}$ \\
\hline Thickness $(\mu \mathrm{m})$ & 1.5 & 1.0 & 1.0 & 2.5 \\
\hline$E_{g}(\mathrm{eV})$ & 1.78 & 1.65 & 1.90 & 2.23 \\
\hline$E_{a}(\mathrm{eV})$ & 4.47 & 4.20 & 3.70 & 4.0 \\
\hline$\varepsilon_{r}$ & 10 & 18 & 18 & 19 \\
\hline$N_{D}\left(1 / \mathrm{cm}^{3}\right)$ & $1 \times 10^{19}$ & $1 \times 10^{19}$ & $1 \times 10^{19}$ & $1 \times 10^{19}$ \\
\hline$N_{A}\left(1 / \mathrm{cm}^{3}\right)$ & $1 \times 10^{19}$ & $1 \times 10^{19}$ & $1 \times 10^{19}$ & $1 \times 10^{19}$ \\
\hline$\mu_{n}\left(\mathrm{~cm}^{2} / \mathrm{V}_{\mathrm{S}}\right)$ & 4.4 & 4.4 & 4.4 & 4.4 \\
\hline$\mu_{p}\left(\mathrm{~cm}^{2} / \mathrm{V}_{\mathrm{s}}\right)$ & 2.5 & 2.5 & 2.5 & 2.5 \\
\hline
\end{tabular}

\section{RESULTS AND DISCUSSION}

\subsection{Effect of Absorbing Layer Band Gap}

In this section, various optimal values of the physical parameters, including absorbing layer thickness, device temperature and defect density of halide based absorbing materials $\left(\mathrm{Cs}_{2} \mathrm{TiBr}_{6}, \mathrm{Cs}_{2} \mathrm{TiI}_{6}, \mathrm{Cs}_{2} \mathrm{TiCl}_{6}\right.$, and $\mathrm{Cs}_{2} \mathrm{TiF}_{6}$ ) have been taken for simulation study under the $300 \mathrm{~K}$. The values of the absorbing layer band gap vary in the range of $1.6-2.4 \mathrm{eV}$. Here, Fig. 2 shows the changes in $J_{S C}$ and PCE with the band gap variation of the absorbing layer. Theoretically, band gap optimization is important to synthesize an optimized band gap active layer experimentally. From Fig. 2a, it is clearly observed that $J_{S C}$ decreases continuously with the band gap for $\mathrm{Cs}_{2} \mathrm{TiBr}_{6}, \mathrm{Cs}_{2} \mathrm{TiI}_{6}, \mathrm{Cs}_{2} \mathrm{TiCl}_{6}$ absorbing layer PSC and for $\mathrm{Cs}_{2} \mathrm{TiF}_{6}$ absorbing layer PSC; initially $J_{S C}$ increases up to $1.8 \mathrm{eV}$ band gap, then it decreases continuously. Similarly, PCE decreases drastically with the band gap of $\mathrm{Cs}_{2} \mathrm{TiI}_{6}, \mathrm{Cs}_{2} \mathrm{TiCl}_{6}$ absorbing layer based PSC and for $\mathrm{Cs}_{2} \mathrm{TiBr}_{6}, \mathrm{Cs}_{2} \mathrm{TiF}_{6}$ PSC the PCE decreases after the $1.8 \mathrm{eV}$ which can be seen in Fig. 2b. The probable reason behind that decrement in the $J_{S C}$ and PCE is much wider band gap of the absorbing layer is leads to less absorption of photons and as a result, low amount of photo-excited carrier is generated in the device. Thus, both the $J_{S C}$ and PCE show decreasing trends with the band gap $[17,18]$.
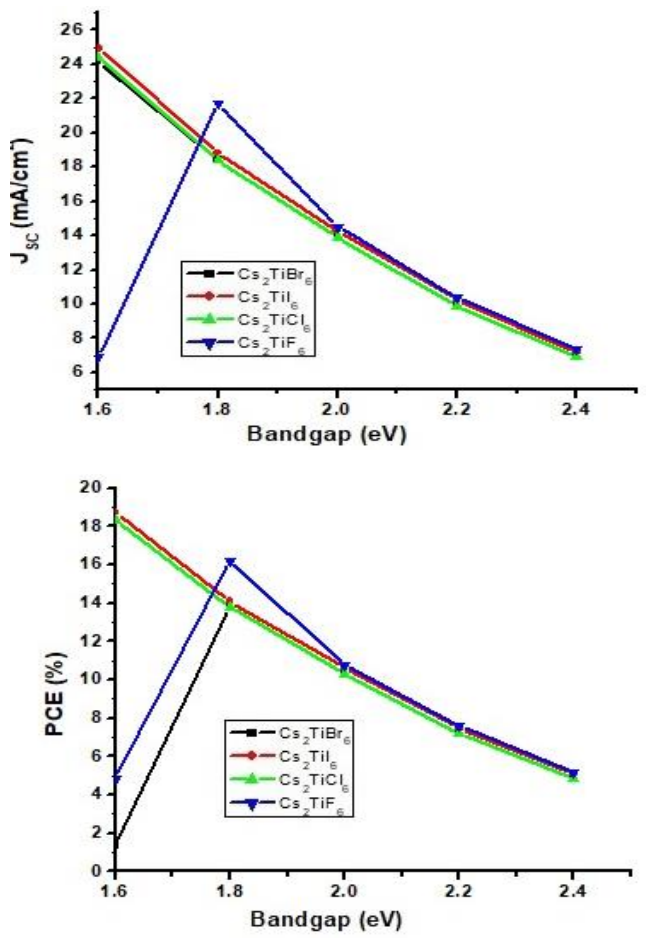

Fig. 2 - Variation in a) $J_{S C}$ and b) PCE with the band gap of the absorbing material

\subsection{Effect of Light Illumination Spectrum}

In this section, the impact of various light illumination under wavelength of $4001000 \mathrm{~nm}$ on the perovskite solar cell has been studied to analyze the photovoltaic performance of the device. Here, Fig. 3 shows the variation in $J_{S C}$ and PCE with the different wavelength. From this figure it is clear that, $\mathrm{Cs}_{2} \mathrm{TiBr}_{6}, \mathrm{Cs}_{2} \mathrm{TiI}_{6}$, and $\mathrm{Cs}_{2} \mathrm{TiF}_{6} \mathrm{PSC}$ have almost constant $J_{S C}$ up to $800 \mathrm{~nm}$ and after that there is a slight jump in the $J_{S C}$ is observed but for the $\mathrm{Cs}_{2} \mathrm{TiCl}_{6} \mathrm{PSC} J_{S C}$ decreases after $800 \mathrm{~nm}$ wavelength. As the $J_{S C}$ is constant up to $800 \mathrm{~nm}$ wavelength, the PCE starts to fall from the $400-800 \mathrm{~nm}$ wavelength for the $\mathrm{Cs}_{2} \mathrm{TiBr}_{6}, \mathrm{Cs}_{2} \mathrm{TiI}_{6}$, and $\mathrm{Cs}_{2} \mathrm{TiF}_{6}$ absorbing layer based PSC and the maximum PCE is recorded as $36 \%$ approximately at $410 \mathrm{~nm}$ wavelength. On the other hand, PCE fall drastically from $450 \mathrm{~nm}$ wavelength for the $\mathrm{Cs}_{2} \mathrm{TiCl}_{6}$ absorbing layer based PSC and the highest PCE is recorded as $29 \%$ at $460 \mathrm{~nm}$ wavelength. The PCE is depending upon the collection of electron-hole pair generation at the wider wavelength. So, as the illumination wavelength increases, electron-hole pair recombination also increases that leads to decrement in the PCE [19]. 

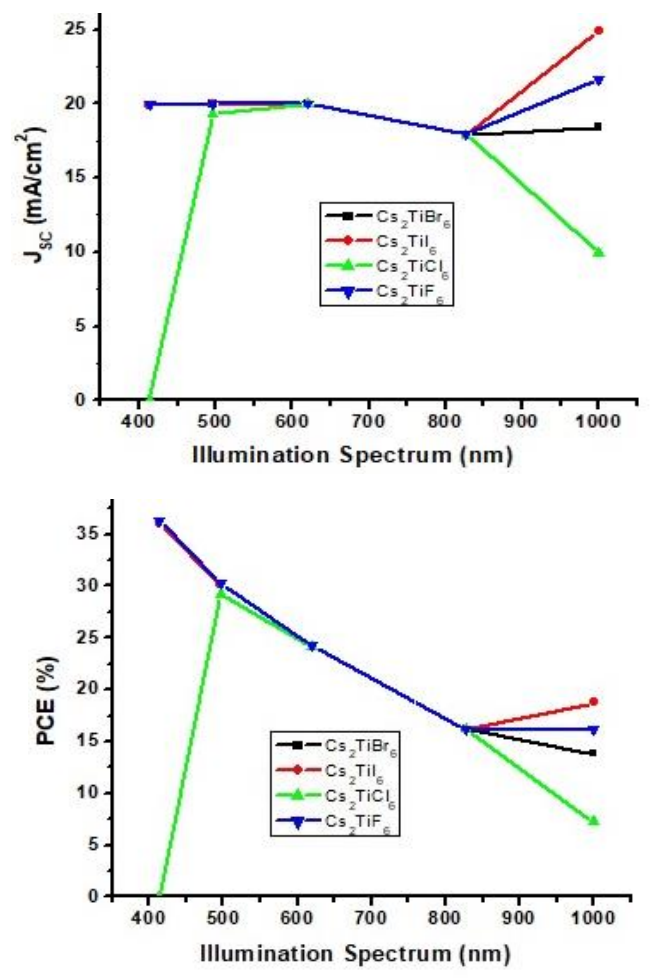

Fig. 3 - Variation in a) $J_{S C}$ and b) PCE with the light illumination spectrum

\section{REFERENCES}

1. A. Kojima, K. Teshima, Y. Shirai, T. Miyasaka, J. Am. Chem. Soc. 131, 6050 (2009).

2. F. Giustino, H.J. Snaith, ACS Energy Lett. 1, 1233 (2016).

3. S.D. Stranks, G.E. Eperon, G. Grancini, C. Menelaou, M.J. Alcocer, T. Leijtens, L.M. Herz, A. Petrozza, H.J. Snaith, Science 342, 341 (2013).

4. W.S. Yang, J.H. Noh, N.J. Jeon, Y.C. Kim, S. Ryu, J. Seo, Science 348, 1234 (2015).

5. W.J. Yin, J.H. Yang, J. Kang, Y. Yan, S.H. Wei, J. Mater. Chem. A 3, 8926 (2015).

6. M.G. Ju, M. Chen, Y. Zhou, H.F. Garces, J. Dai, L. Ma, N.P. Padture, X.C. Zeng, ACS Energy Lett. 3, 297 (2018).

7. M. Chen, M.G. Ju, A.D. Carl, Y. Zong, R.L. Grimm, J. Gu, X.C. Zeng, Y. Zhou, N.P. Padture, Joule 23, 558 (2018).

8. W. Ke, G.M. Kanatzidis, Nat. Commun. 10, 965 (2019).

9. N. Chaudhary, R. Chaudhary, J.P. Kesari, A. Patra, S. Chand, J. Mater. Chem. C 3, 11886 (2015).

10. Y. Yang, J. You, Nature 544, 155 (2017).

\section{CONCLUSIONS}

This research article represents the two aspects of design issues of $\mathrm{FTO} / \mathrm{TiO}_{2} / \mathrm{Cs}_{2} \mathrm{TiX}_{6} / \mathrm{CuSCN} / \mathrm{Ag}$ based PSC, band gap of the absorbing layer and light illumination spectrum. The studies show that $\mathrm{Cs}_{2} \mathrm{TiBr}_{6}$, $\mathrm{Cs}_{2} \mathrm{TiF}_{6}$ absorbing layers have maximum $\mathrm{PCE}$ at the $1.80 \mathrm{eV}$ band gap, and $\mathrm{Cs}_{2} \mathrm{TiI}_{6}, \mathrm{Cs}_{2} \mathrm{TiCl}_{6}$ absorbing layers have maximum PCE at the $1.60 \mathrm{eV}$ band gap. Similarly, at $400 \mathrm{~nm}$ wavelength highest PCE (36 \%) can be achieved for $\mathrm{Cs}_{2} \mathrm{TiBr}_{6}, \mathrm{Cs}_{2} \mathrm{TiI}_{6}$, and $\mathrm{Cs}_{2} \mathrm{TiF}_{6}$ absorbing layers and at $450 \mathrm{~nm}$ wavelength $29 \% \mathrm{PCE}$ can be achieved for the $\mathrm{Cs}_{2} \mathrm{TiCl}_{6}$ absorbing layer based PSC. This simulation-based study can be useful for the selection of desired material at optimal design condition.

\section{ACKNOWLEDGEMENTS}

The authors are grateful to the Department of Electronics and Information systems, University of Gent, Belgium, and Prof. Burgelman for providing the SCAPS software for our research. The authors are also thankful to the Science and Engineering Research Board (SERB), Department of Science and Technology (DST) India for their financial support (EMR/2016/002430) to carry out this research work.
11. S. Bishnoi, S.K. Pandey, IET Optoelectron. 12, 185 (2018).

12. H. Heriche, Z. Rouabah, N. Bouarissa, Int. J. Hydrog. Energy 42, 9524 (2017).

13. N. Khoshsirat, N.A.M. Yunus, IEEE Conf. Sustainable Utilization and Development in Engineering and Technology 1, (2013).

14. M. Mostefaoui, H. Mazar, S. Khelifi, Energy Procedia 74, 736 (2015)

15. K. Chakraborty, M.G. Choudhury, S. Paul, Sol. Energy 194, 886 (2019)

16. K. Chakraborty, M.G. Choudhury, S. Paul, IEEE J. Photovol. 11, 386 (2021).

17. L. Huang, X. Sun, C. Li, R. Xu, J. Xu, Y. Du, Y. Wu, J. Ni, H. Cai, J. Li, Z. Hu, J. Zhang, Sol. Energy Mater. Sol. C. 157, 1038 (2016)

18. K. Tan, P. Lin, G. Wang, Y. Liu, Z. Xu, Y. Lin, Solid-State Electron. 126, 75 (2016).

19. R. Pandey, R. Chaujar, Superlattice. Microstr. 100, 656 (2016).

\title{
Вплив ширини забороненої зони активного шару та освітленості на продуктивність пристрою PSC на основі одиночного галогеніду $\mathrm{Cs}_{2} \mathrm{TiX}_{6}$
}

\author{
K. Chakraborty ${ }^{1}$, S. Paul 1 , U. Mukherjee 2 , S. Das ${ }^{3}$
}

${ }^{1}$ Advanced Materials Research and Energy Application Laboratory, Department of Energy Engineering, NorthEastern Hill University, Shillong-793022 Meghalaya, India

2 Department of Life Science, VTT College, Midnapore-721101 West Bengal, India

${ }^{3}$ Department of Electronics and Communication Engineering, IMPS College of Engg. and Tech., Malda 732103, West Bengal, India

Комплексне дослідження впливу ширини забороненої зони активного шару та освітленості на продуктивність пристрою було проведено для перовскітного сонячного елемента (PSC) на основі $\mathrm{FTO} / \mathrm{TiO}_{2} / \mathrm{Cs}_{2} \mathrm{TiX}_{6} / \mathrm{CuSCN} / \mathrm{Ag}$ з використанням одновимірного симулятора емності сонячних елементів 
(SCAPS-1D). Сучасна стратегія проектування пристрою для оптимізації струму короткого замикання $\left(J_{S C}, \mathrm{MA} / \mathrm{cm}^{2}\right)$, ефективності перетворення енергії (PCE, \%) за рахунок зміни ширини забороненої зони поглинаючого шару та спектру освітленості була досліджена при оптимальних значеннях товщини, температури пристрою і щільності дефектів. Величини різних параметрів, використаних при моделюванні пристрою, було взято з попередньої роботи. Дане дослідження виявило, що для пристрою на основі поглинаючих шарів $\mathrm{Css}_{2} \mathrm{TiBr}_{6}$ та $\mathrm{Cs}_{2} \mathrm{TiF}_{6}$ максимальне значення $\mathrm{PCE}$ спостерігається при ширині забороненої зони $1,80 \mathrm{eB}$, тоді як для пристрою $\mathrm{PSC}$ на основі поглинаючих шарів $\mathrm{Cs}_{2} \mathrm{TiI}_{6}$ та $\mathrm{Cs}_{2} \mathrm{TiCl}_{6}$ максимальне значення РCE досягнуто при ширині забороненої зони 1,60 еВ. 3 іншого боку, оптимальне значення PCE можна досягти при освітленні з довжиною хвилі 400 нм для PSC на основі поглинаючих шарів $\mathrm{Cs}_{2} \mathrm{TiBr}_{6}, \mathrm{Cs}_{2} \mathrm{TiI}_{6}$ та $\mathrm{Cs}_{2} \mathrm{TiF}_{6}$. Для пристрою PSC на основі поглинаючого шару $\mathrm{Cs}_{2} \mathrm{TiCl}_{6}$ зафіксовано максимальне значення РСЕ при довжині хвилі 450 нм і різному освітленні.

Ключові слова: Перовскітний сонячний елемент, SCAPS-1D, Фотоелектричний, Ширина забороненої зони, Освітленість. 